\title{
Deeltydse predikante in die \\ Nederduitsch Hervormde Kerk van \\ Afrika $^{1}$
}

\author{
B J van Wyk \& S J Botha \\ Departement Kerkgeskiedenis \\ Universiteit van Pretoria
}

\begin{abstract}
Part-time ministers in the Nederduitsch Hervormde Church in Africa

This article points out that the Polity of the Nederduitsch Hervormde Church's has a definite background which can be described as Biblical Reformative Theology. It finds its typification in the Presbyterial-synodal church order. With special reference to the Presbyterial-synodal church order, the office of the pastor is seen as a full-time, functional ministry, based on the calling of God. Pastors dedicates themselves to their full-time ministry. The article refers also to the clause with regard to the appointment of part-time ministers. It concludes that practical considerations were decisive and not the principles of the Biblical Reformative Theology and its Presbyterial-synodal background.
\end{abstract}

Die Kerkorde wat in die Nederduitsch Hervormde Kerk gebruik word het 'n historiese agtergrond en aanloop en verwoord 'n omlynde uitgangspunt wat in die verlenging gevind word van die enersyds Bybels-Reformatoriese teologie, en die kerkregtelike verlenging daarvan naamlik, Presbiteriaal-sinodaal. Die Kerkorde verwys na eersgenoemde wanneer gestel word dat predikante wat teologie doseer die Bybels-Reformatoriese teologie deur navorsing, publikasie, voordragte en dosering, asook deur leiding aan nagraadse studente moet bevorder (Nederduitsch Hervormde Kerk van Afrika

\footnotetext{
${ }^{1}$ Hierdie artikel is gebaseer op dr B J van Wyk se PhD proefskrif, getitel "Die Kerkorde en die kerklike reg in die Nederduitsch Hervormde Kerk van Afrika aan die hand van die Presbiteriaal-sinodale kerkbegrip". Die proefskrif is voorberei onder leiding van prof dr S J Botha, Fakulteit Teologie, Universiteit van Pretoria (2005).
} 


\section{Deeltydse predikante in die Nederduitsch Hervormde Kerk van Afrika}

2001=NHKA 2001c:8; Ordereël 2.1.6.1 [c]). ${ }^{2}$ In die omskrywing van die opdrag wat die ring aan visitasiekommissies gee word ook daarna verwys en aangedui dat dit die manier is van waaruit die eenheid tussen gemeentes gehandhaaf word (Ordinansie 3.4.2 [vi] [b]) en om die rede by predikante bevorder moet word (Ordinansie 3.4.2 [vi] [d]). Verder het die Hervormde Kerk reeds in 1967 bevestig dat die Presbiteriaal-sinodale stelsel van kerkregering die stelsel is wat in die Hervormde Kerk gehandhaaf moet word (NHKA 1967:179).

Daarom is dit begryplik dat die kerkordelike omlyning met betrekking tot die amp wat in die Kerkorde neerslag gevind het, die gevolg is van die denke wat in die Presbiteriaal-sinodale stelsel van kerkregering wat onder leiding van Calvyn sedert die Ordinances Ecclésiastiques 1541 in Genève (Plomp 1969:166 e v), die Discipline Ecclésiastique 1559 in Parys (Pont 1981:48 e v), asook langs die verdere kerkregtelike ontwikkeling veral op Nederlandse bodem sedert die Konvent van Wezel 1568 tot en met die Dordtse Sinode van 1618-19 vorm aangeneem het.

Die voltydse amp van die dienaar van die Woord volgens die Presbiteriaal-sinodale stelsel, is ' $n$ funksionele ampsbeskouing. Dit kom daarop neer dat iemand predikant kan wees omdat hy die dienswerk eie aan die amp van predikant verrig. "Dit beteken dat iemand slegs in die amp kan staan as hy ook ampswerk verrig. Sodra die dienaar nie meer die ampswerk doen nie, het die amp in beginsel verval, want die amp is nié 'n officium, 'n hooggeplaaste posisie nie, maar 'n ministerium of wel dienswerk" (Pont 1981:201; [1976]:177; Goumaz 1964:47). Die sogenaamde funksionele ampsbeskouing is nie net deel van die kerkregtelike besinning van die Nederduitsch Hervormde Kerk nie, maar 'n voor die hand liggende uitgangspunt van die kerkregtelike stelsel wat in die Kerk beoefen word na keuse naamlik, Presbiteriaal-sinodaal. Wanneer dit gestel word kom die Reformatoriese erfenis van die Kerk ter sprake en beteken in díe verband dat die funksionele ampsbeskouing tot sover as Calvyn teruggevoer kan word wat grondliggende kerkregtelike vormgewing daargestel het. "Om dus as 'n ware dienaar van die kerk geag te word, moet iemand eers behoorlik beroep wees; daarna moet hy op die beroep antwoord, dit beteken dat hy die take wat hom opgelê is, moet onderneem en uitvoer" (Calvyn 1992:1326). Ainslie (1940:40) beklemtoon die feit wanneer hy sê: "The most important work of the Reformed minister had to be preaching. There could be no true ministry without it. If a

\footnotetext{
${ }^{2}$ Ordereëls en Ordinansies word verder direk gesiteer en verwys na die Kerkorde wat tydens die ses en sestigste Algemene Kerkvergadering in 2001 vasgestel is. Eweneens verwys Bepalings van die Kerkwet na die Kerkwet vasgestel tydens die drie en sestigste Algemene Kerkvergadering in 1992. Sedert 1997 is die benaming Kerkwet vir die ordereëls van die Kerk vervang deur die meer korrekte begrip Kerkorde. Daarom is die Kerkwet en die Kerkorde twee verskillende dokumente aangesien laasgenoemde in die plek van eersgenoemde gekom het sedert 1997.
} 
man, who was supposed to be in a ministerial order, did not preach, that was sufficient to disqualify him from being a true minister of the Church." Hierby sluit Milner aan wanneer hy dit het oor Calvyn se ekklesiologie en na aanleiding daarvan sê: "He is truly the servant of God, then, who faithfully and obediently fulfills the office which has been entrusted to him, and does not merely seek self-aggrandizement through nominal assumption of office" (Milner 1970:136). In die Kerkorde wat in Parys in 1559 vir die Franse Kerk opgestel word, die Discipline Ecclésiastique word in Artikel 12 gestel: "Hy wat eenmaal tot die diens van die Woord beroep is, moet weet dat hy daarmee vir sy hele lewenstyd tot dié diens verkies is" (Pont 1981:51).

Die dienswerk wat aan die predikant toevertrou is was ook voorafgegaan deur 'n roeping wat van God ontvang en wesenlik is vir die bedienaar van die Woord. Daarop het Calvyn eweneens klem gelê (Calvyn 1992:1327; Milner 1970:139).

Die klem wat op roeping tot die amp geplaas is het ook in die Lutherse tradisie na vore gekom. In die Augsburgse Geloofsbelydenis, onder andere, word die saak soos volg geformuleer: "Vom Kirchenregiment wird gelehrt, dass niemand in der Kirche öffentlich lehren oder predigen oder Sakramente reichen soll ohne ordentliche Berufung" (Steubing 1985:44).

Die profiel van die bedienaar van die Woord soos gesien deur Calvyn en verder verwoord in die vormgewing van die Presbiteriaal-sinodale kerklike reg wat in die Nederduitsch Hervormde Kerk beoefen word (NHKA 1967:79; Pont 1981:3), bestaan uit 'n geroepe ampsdraer wat die dienswerk kenmerkend van 'n bedienaar van die Woord, voltyds uitvoer (Pont 1976:180; 1978:51 vv). Daarom is dit nie vreemd nie dat die Kerkorde die saak ook so formuleer wanneer gestel word: "(d)ienaars van die Woord is deur God geroep, deur die Kerk tot die evangeliebediening toegelaat en in die amp bevestig. Die voorreg van Woordverkondiging en sakramentsbediening is aan hierdie diens verbonde" (Ordereël 2.1). Laasgenoemde sin dui op die funksionele ampsbeskouing asook op die feit dat 'n bedienaar van die Woord nie oor status beskik nie, maar ampsvoorreg geniet wat beteken dat die dienswerk verrig word wat kerkordelik aan die amp verbind word.

Die Kerkorde van die Nederduitsch Hervormde Kerk laat hom in die tweede hoofstuk uit oor die amp nadat die belydenis in die eerste hoofstuk ter sprake gebring is. In die teologiese debat is al opgemerk dat die belangrikheid wat die amp in die Hervormde Kerk inneem gereflekteer word in die feit dat die amp slegs deur die belydenis voorafgegaan word (Van Aarde \& Pelser 2001:22), en waarskynlik kan ook in die verband verwys word na die ruimte wat in die Kerkorde aan die amp gewy word. Die saak kan nader gepresiseer word deur daarop te wys dat die Kerkorde slegs ongeveer vier bladsye aan die ouderling en diaken bestee uit 'n totaal van 29 bladsye waar die amp ter 


\section{Deeltydse predikante in die Nederduitsch Hervormde Kerk van Afrika}

sprake kom. Behalwe moontlik ander redes is die mees voor die hand liggende kerkordelike rede waarskynlik daarin te vinde dat die amp van bedienaar van die Woord voltyds beoefen word teenoor die ampte van ouderling en diaken wat slegs deeltyds funksioneer. Daarom kan by laasgenoemde slegs volstaan word met 'n inhoudelike beskrywing van die ampswerk van die ouderling en diaken.

In die verband word daarop gewys dat met die ingebruikneming van die Kerkorde uitgegaan is van die standpunt dat die amp van die bedienaar van die Woord ' $n$ voltydse amp is, ongeag of van dienaars van die Woord in gemeentes sprake is of predikante met besondere opdrag. Die mate waarin die ampswerk van die predikant volledig beslag lê op al die tyd en aandag van die predikant word duidelik wanneer na Ordinansie 2.1.5 verwys word. Die Ordinansie behandel die inhoud van die ampswerk van die predikant in rangorde en dit verbaas nie dat verkondiging van die Woord en bediening van die sakramente as die belangrikste deel van die dienswerk van predikante beskou word nie (Ordinansie 2.1.5 [i]). Daarop volg huisbesoek wat steeds gesien word as dienswerk wat jaarliks by al die lidmate verrig word, en so gehandhaaf moet word behalwe wanneer met die ouderlingevergadering 'n ander reëling getref is. Die byvoeging "soos met die ouderlingevergadering ooreengekom" beklemtoon die opsigtaak van die ouderlinge oor die predikant in die verband (Ordinansie 2.1.5 [ii]). Die Ordinansie is redelik breedvoerig oor die ampswerk van die predikant en dit val op dat ook van 'n predikant verwag word om planmatige studie in die teologie te doen (Ordinansie 2.1.5 [xv]). As geheel beskou is dit vanselfsprekend dat ' $n$ predikant al sy tyd en aandag aan sy dienswerk sal wy en in die lig van die kerkordelike beskouing volgens bogenoemde Ordinansie, vanselfsprekend.

Die toelating van deeltydse predikante tydens die ses en sestigste Algemene Kerkvergadering van die Nederduitsch Hervormde Kerk was ' $n$ afwyking van die kerkregtelike tradisie wat in die Kerk ter sprake is, alhoewel nie 'n totaal nuwe verwikkeling op kerkregtelike terrein nie.

In die jare vyftig en daarna toe daar 'n tekort aan predikante was, het die Kerk toegelaat dat sommige wat wesenlik tot ' $n$ ander lewenstaat oorgegaan het op kansels van die Hervormde Kerk verskyn sonder dat hulle aan 'n vaste werkkring in die Kerk verbonde was (Pont [1973]:99). Die invoering van die deeltydse predikant het spreekwoordelik die kerkregtelike roer omgegooi omdat daarmee ' $n$ figuur ingevoer is wat nie in die funksionele ampsbeskouing wat eie aan die Hervormde Kerk se kerkregtelike denke tot op datum was, ingepas het nie. Pont ([1973]:108) lewer daaroor die volgende kritiese kommentaar: "Vir my opvatting het die Algemene Kerkvergadering met hierdie besluit 'n streep getrek deur die Bybels-Reformatoriese 
ampsopvatting en die amp verlaag byna tot op die vlak waar dit 'n winsgewende by-inkomste kan wees vir manne wat wél die bevoegdheid maar nie die lus of die toewyding het om die opdrag van die amp, die roeping van God permanent-voltyds te dra nie". Naas die funksionele ampsbeskouing wat eie is aan die Presbiteriaal-sinodale stelsel het die tydelik-deeltydse predikant dus sy verskyning gemaak van wie die NHKA se Algemene Kerkvergadering van 1970 nie net geoordeel het dat dit moontlik is nie, maar ook noodsaaklik, en dat dit slegs op 'n differensiasie van die amp neerkom (NHKA 1970:38; Van Wyk 1991:186). Dienaars van die Woord wat nie meer aan 'n standplaas verbonde was nie het reëlmatig op kansels verskyn, nie op grond van hulle roeping en bevestiging nie, maar op grond van die feit dat hulle opgeleide dienaars van die Woord was (Pont [1973]:99). Dit het beteken dat enige persoon met die bevoegdheid om dienaar van die Woord te wees, ongeag watter werkkring hy buite die Hervormde Kerk beklee het, deur die Kommissie van die Algemene Kerkvergadering gebruik kon word (Pont [1973]:100). Pont het daarop gewys dat die oorweging nou verskuif het van die roeping en ordening van 'n dienaar van die Woord na die vraag of hy deur die Hervormde Kerk by name van sy Kommissie van die Algemene Kerkvergadering, gebruik kon word. Die inisiatief het duidelik van die Kommissie van die Algemene Kerkvergadering uitgegaan.

Die besluit het waarskynlik gespruit uit 'n debat hoe dit vir diegene wat tot die evangeliebediening toegelaat en verkies het om voltydse dosente aan die Universiteit van Pretoria te wees, maar slegs proponentstatus geniet het, moontlik gemaak kon word om geordende bedienaars van die Woord te wees (NHKA 1970:37). Naas die alternatief om die doktore-amp volledig te laat herleef is gestel dat oorweging geskenk moet word om sodanige dosente as deeltydse predikante te laat beroep en te bevestig in gemeentes in Pretoria. "Op dié manier sou diegene wat reeds in die amp van dienaar van die Woord gestaan het, kan voortgaan met die ampsbediening óf diegene wat kwalifiseer om toegelaat te word tot die amp, sou dan op hierdie wyse tot die amp toegelaat kan word" (Pont 1969:6). Pont het na die presedent verwys wat geskep is toe prof Gisbertus Voetius in Maart 1637 as professor van die Universiteit van Utrecht as mede-predikant beroep is, as 'n moontlikheid dat die Kerk ook iets dergeliks kan oorweeg om die dosente in teologie en voorbereidende vakke te akkommodeer (eie kursivering).

Die Algemene Kerkvergadering van 1970 (NHKA 1970:38) het egter die saak oopgegooi sodat elkeen wat oor 'n teologiese opleiding beskik het deur die Kommissie gebruik kan word, ongeag of hy die begeerte het om weer dienaar van die Woord te wees. 
Die oorweging is nou níe meer die vraag of iemand hom deur God geroepe voel om in Sy diens Woord en Sakrament te bedien nie, maar die pragmatiese oorweging of hy "gebruik" kan word om tydelik-deeltyds 'n amp te vul wat níe as voltyds-permanente roeping en taak aantreklik genoeg is nie.

(Pont [1973]:101)

Deeltydse predikante het op die manier kerkordelike beslag in die Kerkwet van die Kerk gekry. Dit was nie vir die Algemene Kerkvergadering of sy Kommissie 'n probleem dat die funksionele ampsbeskouing van die Presbiteriaal-sinodale stelsel hiermee deurkruis is nie. In die verband het 'n memorandum van Engelbrecht (1982:123), onder andere, voor die vergadering gedien waarin samevattend die volgende gestel is:

Gesien bostaande Reformatoriese ampsleer lyk dit tog moontlik dat die Kerk sekere persone wat daarvoor opgelei is, in tydelike, deeltydse hoedanigheid vir bepaalde dienste kan roep indien die Kerk daarvan oortuig is dat die persoon geskik is en indien die Kerk daarvan oortuig is dat nòg die tydelikheid nòg die deeltydse karakter die bepaalde werkopdrag sal skaad.

Die besluit het in die Kerkwet (NHKA 1992:78; Bepaling 162.3 (b)) beslag gekry en daarmee deel geword van die ampspraktyk van die Nederduitsch Hervormde Kerk totdat die Kerkwet deur die Kerkorde in 1997 vervang is. Behalwe die deeltydse predikant was daar in die Kerkwet ook ander moontlikhede naamlik, dat 'n Hervormde predikant deur die Kommissie van die Algemene Kerkvergadering vir 'n besondere opdrag benoem kon word om werksaam-hede vir 'n bepaalde of onbepaalde tyd te doen wat nie administratiewe take ingesluit het nie, asook benoem kon word om 'n bepaalde administratiewe taak te hanteer (Bepaling 1501 en 2). Verder was daar ook die figuur van die pastorale hulp wat pastorale werk in 'n gemeente gedoen het. Hy of sy is nie beroep of bevestig nie en sy of haar ooreenkoms met betrekking tot sy of haar pligte in die gemeente waar hy of sy pastorale hulp verleen het was per notule gereël [Bepaling 162 2(a)]. Verder het die Kerkwet van die NHKA ook bepaal dat 'n pastorale hulp slegs sodanig vergoed word wat hom in staat gestel het om die dienswerk waartoe hy verbind is, te verrig [Bepaling 162 2(b)].

Persone wat as pastorale hulp gebruik kon word was predikante in besondere diens, deeltydse predikante, teologiese dosente, emeriti en diegene met predikantstatus wat nie in 'n gemeente bevestig is nie (Bepaling 162 3[a-f0; kyk ook Bepaling 102.1[c]). 
Met die invoering van die Kerkorde in 1997 is nie net weggedoen met die deeltydse predikant nie, maar ook met die pastorale hulp, asook predikante wat nie aan 'n vaste werkplek verbonde was nie, maar tog "predikantstatus" behou het. Laasgenoemde was as sodanig 'n skerp afwyking van die funksionele ampsbeskouing. Verder is die predikant wat 'n besondere opdrag behartig wat administratief van aard was volgens Bepaling 150.2, ook gelaat. Daarnaas het van die besluit van die NHKA se twee en sestigste Algemene Kerkvergadering van 1989 met betrekking tot die tentmakerbediening, ook nie veel tereg gekom nie. Dit was niks anders as die deeltydse predikant nie. Die volgende uitspraak bevestig dit. "Die tentmakerbediening verskil in die opsig van die van ' $n$ voltydse predikant dat hy net 'n gedeelte van sy werkstyd aan sy bediening wy en tegelyk ' $n$ ander betrekking beklee wat hom gedeeltelik of totaal van sy lewensonderhoud voorsien" (NHKA 1989:26).

Die Kerkorde het van die standpunt uitgegaan dat die Hervormde Kerk oor geroepe bedienaars van die Woord beskik, hetsy predikante wat in gemeentes staan, of emeriti. Daarnaas is tog iets behou van die Kerkwet in die vorm van die predikant met besondere opdrag (Ordereël 2.1.1; 2.1.6). Tog het hier 'n uitbreiding gekom naamlik, dat 'n besondere opdrag nie net vanweë die NHKA se Kommissie van die Algemene Kerkvergadering moontlik was nie, soos onder Bepaling 150.1, maar volgens Kerkorde word iemand vir 'n besondere opdrag benoem deur die Algemene Kerkvergadering, 'n ringsvergadering of ' $n$ kerkraadsvergadering (Ordinansie 2.1.17.2).

Die bedoeling van die Kerkorde was om te beklemtoon dat die Hervormde Kerk slegs oor geroepe bedienaars van die Woord beskik wat al hulle tyd en aandag aan die Hervormde Kerk se dienswerk gee. Daarnaas is egter ook rekening gehou met die situasie waarin die Hervormde Kerk tans verkeer waar ekonomies-maatskaplike druk daarop uitgeloop het dat gemeentes onder finansiële druk verkeer en predikante gevolglik nie meer kan vergoed volgens die maksimum-minimum van die skale van die Administrateur nie. Die Kerkorde bepaal gevolglik dat aan 'n standplaas volle, gedeeltelike of geen versorging nie, verbonde is (Ordinansie 2.1.2.1 [ii]). Daarom het die NHKA se vyf en sestigste Algemene Kerkvergadering reeds besluit dat slegs van "predikante gepraat word en nie van deelsorg- of deeltydse predikante nie. Daar word gepraat van standplase. Die standplaas wat geskep word bepaal die wyse van beroep naamlik: volledige versorging; deelversorging; deeltydse bediening; benoeming vir 'n besondere opdrag. Daar is dus net standplase met deelversorging en standplase met deeltydse bediening en nie deelversorgde predikante en deeltydse predikante nie" (NHKA 2004:116). Die implikasie is dat die Hervormde Kerk oor predikante beskik wat geroepe is om hulle amp in die Hervormde Kerk voltyds uit te voer, 


\section{Deeltydse predikante in die Nederduitsch Hervormde Kerk van Afrika}

maar vanweë ekonomies-maatskaplike redes verplig word om dié voltydse roeping in standplase uit te voer waar volle versorging nie moontlik is nie.

Die besluite wat op die NHKA se ses en sestigste Algemene Kerkvergadering geneem is na aanleiding van die verslag van die Raad vir Pastoraat en Presbiteraat (NHKA 2001b:138-162) toon uit die aard van die saak 'n afwyking met betrekking tot die Presbiteriaal-sinodale kerkbegrip. Die voorstelle wat tydens die vergadering geformuleer is het wesenlik die situasie soos verwoord deur die Kerkwet, heringevoer. Die deeltydse predikant is weer die kerk binnegedra met dieselfde motivering, behalwe dat daar in 1970 'n tekort aan predikante was teenoor die oorvoorsiening tans.

Sedert die NHKA se ses en sestigste Algemene Kerkvergadering is die moontlikheid om 'n deeltydse predikant te wees weer geskep, maar terselfdertyd verder gegaan as in 1970 omdat 'n predikant ampsvoorreg kan behou, sonder om aan 'n vaste werkplek in die Hervormde Kerk verbonde te wees. Die vergadering het ook verder gegaan as in 1970 aangesien deeltydse predikante permanent geword het sonder die beperking van tydelik of deeltyds. Die deeltydse predikant wat hiermee vir die tweede keer ingevoer is verteenwoordig 'n radikale verandering van denke in die ampsbegrip van die Hervormde Kerk. As kritiese opmerking word daarop gewys dat deeltydse bediening nie beperk is tot diegene wat voltyds predikant wil wees maar in afwagting van 'n voltydse standplaas, bereid is om sy lewenstog buite die Hervormde Kerk aan te vul nie. Die Kerkorde het in effek reeds vir die moontlikheid voorsiening gemaak aangesien aan 'n standplaas volle, gedeeltelike of selfs geen versorging verbonde is (Ordinansie 2.1.2.1 [ii]).

Die deeltydse predikant is volgens die huidige formulering ' $n$ persoon wat 'n doelbewuste keuse kan uitoefen om níe al sy tyd en aandag aan die dienswerk van predikant te bestee nie, maar die oorwig van sy tyd aan 'n beroep búíte die Kerk te wy. Die opstellers van die verslag aan die ses en sestigste Algemene Kerkvergadering het korrek aangevoel dat 'n predikant wat net deeltyds betrokke wil wees se roepingsbewustheid bevraagteken kan word. Daarop volg egter die opmerking: "Die vraag is egter of die uitgangspunt nie eerder die volledige bediening van die gemeente moet wees as sekere geykte beskouings van die amp nie." Op dieselfde bladsy word redes verstrek waarom deeltydse bediening oorweeg moes word naamlik, sodat bekostigbare predikantsbediening en selfs meerdere en gespesialiseerde bediening vir gemeentes sodoende moontlik word, asook om geleentheid te bied tot werkskepping vir beroepafwagtendes/deelsorgpredikante (NHKA 2001a:98).

In die eksegetiese deel van die verslag word nie na die deeltydse predikant verwys nie. Klaarblyklik het die opstellers van die verslag geen 
probleem met die deeltydse predikant nie en in die suiwer praktiese motivering word ook nie enige probleem vermeld nie. Wanneer die funksionele ampsbeskouing hier ter sprake gebring word is dit nader bepaal as 'n "ampsbeskouing wat ten dienste staan van die verkondiging van die evangelie". Die begrip word verder verklaar as gestel word dat

die eise van die dag, dit wat nodig was, aanleiding gegee het tot die totstandkoming van sekere "ampte". As voorbeeld kan hier die "amp" van die apostel genoem word. Omdat daar die behoefte was aan betroubare garante van die inhoud, werk, lewe en implikasie van die lewe van Jesus (dit wil sê, die evangelie van die opgestane Christus), het die "amp" van die apostel (in eng verband gesien), na vore getree.

(NHKA 2001a:102)

Die aanduiding dat die amp van die apostel in die praktyk ontstaan het staan in kontras met die ampsbeskouing wat in die Hervormde Kerk tot dusver gegeld het naamlik, dat die apostelamp en daarmee elke ampsdraer sy roeping van Jesus Christus die Hoof en Heer van die kerk ontvang.

Die verslag stel 'n wysiging van die amp voor sonder 'n beredenering of 'n deeltydse predikant naas 'n voltydse geroepe bedienaar van die Woord Skriftuurlik haalbaar is. Skriftuurlike gegewens soos die selfbekendstelling van die apostel Paulus aan die begin van sy briewe as aanduiding van sy gesag van waaruit hy skryf dui daarop dat hy homself as 'n geroepe apostel gesien het wat eintlik geen ander keuse het nie omdat hy die verkondiging van die evangelie beleef as 'n taak wat aan hom toevertrou is. Hy stel homself voor as 'n slaaf van Christus Jesus (Rom 1:1; Fil 1:1), 'n geroepe apostel (Rom 1:1; 1 Kor 1:1), afgesonder vir die evangelie (Rom 1:1) deur die wil van God (Kol 1:1; Ef $1: 1 ; 1$ Kor $1: 1$ en 2 Kor 1:1). Paulus stel aan die Korintiërs dat hy die evangelie verkondig omdat hy moet, en wee hom as hy dit nie doen nie (1 Kor 9:16). Pelser se opmerking ten opsigte van die dissipelskap in die Markusevangelie staan in kontras met die byderwetse deeltydse predikant wat net 'n gedeelte van sy tyd beskikbaar het om die dienswerk van die kerk te verrig en van die kerk verwag om te glo dat hy waarlik geroepe is om die evangelie te verkondig.

In hierdie verband word vandag algemeen aanvaar dat Markus 8:27-10:45 die gedeelte in die Evangelie is wat van wesenlike belang is vir Markus se verstaan van wat dissipelskap inhou. Hieruit word duidelik hoe nóú dissipelskap en Christologie saamhang. Dit is in hierdie gedeelte "dat Jesus as die lydende Seun van God voorgestel word en die navolgers opgeroep word om in ooreen- 


\section{Deeltydse predikante in die Nederduitsch Hervormde Kerk van Afrika}

stemming met die weg van Jesus bereid te wees om te ly, te dien en die minste te wees".

(Pelser 1995:650)

In die gedeelte kom uitsprake voor soos Markus 8:34-38 en die bekende Markus 10:45 wat tot besondere nadenke spreek en deeltydse bediening in 'n kritiese lig plaas. Hoewel Paulus 'n tentmaker van beroep was en aandui dat lewensmiddele soms ontbreek het (2 Kor 11:27) verkies hy om hom voltyds toe te lê op die verkondiging van die evangelie en sy beroep as tentmaker te verlaat (Hand 18:3-5).

Die situasie wat deur die ekonomies-maatskaplike omstandighede veroorsaak is en 'n wesenlike gevolg in die Hervormde Kerk uitoefen word nie ontken nie. Die kritiese vraag is egter of die hantering van die konteks waarbinne die Hervormde Kerk sy dienswerk verrig genoegsaam rede verskaf om die ampsbegrip as agterhaal en deur omstandighede ingehaal, te beskou. Dat predikante bereid is om slegs met deeltydse versorging hulle roeping voltyds uit te leef, moet met dank geboekstaaf word. Dat sommige selfs bereid is om in die wêreld búíte die kerk 'n aanvullende heenkome te vind, kan slegs tekenend wees van 'n deurleefde roeping. Dat vir andere die amp verpraktiseer moet word om uiting te gee aan hulle keuse om slegs gedeeltelik by die kerk betrokke te wees sodat voltyds 'n beroep buite die kerk beoefen kan word, dui op 'n gees wat nie erns maak met die eiesoortigheid van die kerk nie.

'n Bybels-Reformatoriese teologie word deur die Woord bepaal.

Daarom is daar 'n noue relasie tussen Skrif, belydenis en kerklike orde. Dit is hieraan waaraan die Presbiteriaal-sinodale kerkbegrip uiting gee. Daarom kan dit nie anders nie dat die ampsbegrip as deel van die kerkbegrip, vanuit hierdie vertrekpunt bepaal moet word. Die mening bestaan dat die herinvoering van die deeltydse predikant om praktiese redes geskied en nie deur Skriftuurlike norme gerugsteun word nie. Selfs die praktiese redes wat aangevoer is naamlik dat daarmee bekostigbare bediening moontlik word, is reeds deur die kerkordelike bepaling dat aan 'n standplaas volle, gedeeltelike of geen versorging verbonde is, ondervang. Die verdere onderskeid setel in die belangrike uitgangspunt dat gedeeltelike versorging steeds ' $n$ voltydse roeping veronderstel, wat in praktyk daarop moet neerkom dat 'n bedienaar van die Woord wat slegs gedeeltelik versorg word, die geleentheid tot volle versorging met albei hande sal aangryp (Ordinansie 2.1.3.3 [vi]). Deeltydse predikante is permanent ingevoer maar bestaan onder die implikasie dat hulle nie voltyds beskikbaar is nie aangesien hulle eerste verpligting by die werkgewer in die wêreld buite die kerk geleë is. 
Dit sou verstandiger wees om nie deeltydse bediening in die Kerkorde te reglementeer as nog 'n kategorie van predikante nie, maar die moontlikheid as deel van die besluite van die NHKA se Algemene Kerkvergadering te laat wat as nadere kommentaar van die Ordereëls en Ordinansies van die Kerkorde funksioneer. Daardeur sou ook begrip getoon word dat 'n kerkorde nie 'n notule van kerklike handelinge is nie en dat slegs gereglementeer word wat in 'n kerkorde tuis hoort. Dit sou minstens daarvan getuig dat die Hervormde Kerk vanweë sy funksionele ampsbeskouing uitgaan van die feit dat die bedienaar van die Woord wat in 'n gemeente al sy tyd en aandag aan die Hervormde Kerk wy, die Bybels-Reformatoriese ampsbeskouing verwoord.

Tydens die NHKA se sewe en sestigste Algemene Kerkvergadering is voorstelle om wysiging van Ordinansies goedgekeur om kerkordelik voorsiening te maak vir die deeltydse predikant en die implikasies daarvan in die Hervormde Kerk. Sodoende is Ordinansie 2.1.2.1 uitgebrei om voorsiening te maak vir volle-, gedeeltelike versorging of deeltydse bediening. Dit is dus moontlik dat standplase gewysig kan word na gelang van omstandighede (NHKA 2004:119).

Die slotsom waartoe gekom word wanneer die besluit om deeltydse predikante weer in te voer gemeet word aan die ampsbegrip van die Presbiteriaal-sinodale stelsel, is dat deeltydse predikante ' $n$ vervlakking van die amp beteken. Dit is nie duidelik waarom iemand die teologiese opleiding voltooi en dan volgens eie keuse slegs deeltyds vir die Hervormde Kerk betrokke is nie. Die motivering vir die besluit was onder andere om diegene tegemoet te kom wat verkies om voltyds predikant te wees. Vanweë die ekonomies-maatskaplike situasie van die Hervormde Kerk tans is sommige egter nie daartoe in staat gestel nie. Wie dus in sulke omstandighede bereid is om sy lewenstog buite die kerk aan te vul, getuig van 'n besondere roeping wat met dankbaarheid erken moet word. Die saak word egter problematies as voltydse dienswerk in 'n gemeente gelaat word om 'n ander beroep in die wêreld buite die Hervormde Kerk te volg wat op al die beskikbare tyd van die deeltydse predikant beslag lê. Saam met die besluit om die deeltydse predikant weer in te voer is ook die moontlikheid wat in die Kerkwet bestaan (Bepaling 102 1. (c)) het, dat iemand predikantsvoorreg kan geniet sonder om aan 'n vaste werkplek in die Kerk gebonde te wees, weer geskep (NHKA 2001b:162). Die gevolge van die besluit was duidelik nie bevorderlik vir die ampspraktyk van die Hervormde Kerk nie, aangesien van die kant van die Kommissie van die Algemene Kerkvergade-ing voorstelle tydens die sewe en sestigste Algemene Kerkvergadering ingedien is om Ordinansie 2.1.15 te wysig, sodat diegene wat predikantsvoorreg geniet sonder enige verbintenis aan 'n vaste werkplek in die Kerk, verplig word om met die Kommissie gesprek te voer voor 31 Oktober van elke jaar, en by afwesigheid daarvan 


\section{Deeltydse predikante in die Nederduitsch Hervormde Kerk van Afrika}

ampsvoorreg verbeur teen 1 Januarie die volgende jaar (NHKA 2004:131). Krities beskou is daar ' $n$ leemte in die besluit aangesien pertinent gepraat word van beroepafwagtende predikante en proponente, terwyl die persoon wat van sy kerklike werkplek losgemaak is op eie versoek nie pertinent genoem word nie. Dit is egter duidelik dat diegene ook hierby mutatis mutandis ingesluit moet word aangesien die besluit nie net op beroepafwagtende predikante en proponente van toepassing gemaak kan word indien die funksionele ampsbeskouing enigsins ter sprake is nie.

Die praktyk van deeltydse predikante bestaan ook in die Nederduitse Gereformeerde Kerk in die persoon van die tentmaker. "'n Tentmaker is 'n gemeenteleraar wat deeltyds, soos ooreengekom, die ampspligte van Artikel 9 van die Kerkorde onder lidmate van die gemeente of onder ander persone binne die gemeentegrense vervul" (Nederduitse Gereformeerde Kerk 2002=NGK 2002:99). Terselfdertyd word kerkrade opgeroep om daarteen te waak dat "'n tentmakerspos geskep en/of misbruik word bloot vir die verkryging/behoud van predikantsbevoegdheid of om sitting in kerklike vergaderinge te verkry. "Verder word onderskei tussen 'n tentmaker of deeltydse predikant en 'n pastorale hulp wat 'n kontrakwerker met 'n vasgestelde dienstermyn is, nie 'n tydelike leraarspos is nie, en ook nie na 'n gemeente beroep of bevestig word nie" (NGK 2002:100).

Samevattend is die ampsbeskouing wat werk met 'n geroepe bedienaar van die Woord wat voltyds al sy tyd en aandag daaraan wy 'n bruikbare inset wat uit die Presbiteriaal-sinodale stelsel van kerkregering behou kan word, aangesien dit ook Skriftuurlik en in die belydenis van die kerk omlyn en dus ook kerkordelik bepaal is.

Dat nie met 'n verstarde ampsbegrip gewerk word nie is aanvaarbaar. Voorsiening vir 'n dienaar van die Woord wat sy voltydse roeping nie in 'n vaste werkkring soos die gemeente kan beoefen nie vanweë omstandighede waarin die Hervormde Kerk hom bevind, is ook begryplik. Daar moet egter aanvaar word dat deeltydse bediening 'n afwyking is van die kerkregtelike profiel wat in die ampsbeskouing van die Kerk volgens die Presbiteriaalsinodale stelsel aangetref word. Dit is egter deel van die dinamieka wat onderliggend aan die Kerkorde is om moeilike en veranderde omstandighede waaroor die Kerk nie beheer het nie, die hoof te bied. Dit dui egter nie op 'n veranderde kerkbegrip wat deur die praktyk bepaal word nie, aangesien die uitgangspunt behou word dat bedienaars van die Woord geroepe diensknegte van God is wat begeer om die evangelie voltyds te verkondig. Dit is egter duidelik dat predikante wat doelbewus verkies het om van hulle gemeentes losgemaak te word, of 'n voltydse gemeente laat om voltyds in die wêreld buite die kerk in 'n betrekking betrokke te raak, 'n ernstige afwyking van die funksionele ampsbegrip verwoord en die kerk moeilik sal oortuig van 'n deurleefde roeping. 
Pont ([1973]:117) lewer na aanleiding van die vorige invoering van die deeltydse predikant in 1970 die volgende kommentaar in die verband:

Die ander moontlikheid is natuurlik oop dat die besluit van die Algemene Vergadering van 1971 gehandhaaf sal word. Indien dit sou gebeur sou dit jammer wees omdat daarmee beklemtoon sal word dat die beginsels van die liberale, kollegiale kerkreg, wat weinig verband met Skrif en Belydenis het, vir die Vergadering belangriker is as die Bybels-Reformatoriese kerklike orde. Buitendien sal die handhawing van die figuur van die tydelik-deeltydse predikant, soos hy nou bestaan, alleen maar meewerk om die amp van dienaar van die Woord al meer en meer te sekulariseer. As daar gekies word vir hierdie sekularisasie van die amp sal die troos minstens bestaan dat die kerk byderwets is, maar dit beteken ongelukkig nie Bybels-Reformatories nie.

\section{Literatuurverwysings}

Ainslie, J L 1940. The doctrines of ministerial order in the reformed churches of the $16^{\text {th }}$ and $17^{\text {th }}$ centuries. Edinburgh: T\&T Clark.

Calvyn, J 1992. Institusie van die Christelike Godsdiens, Boek 4. Potchefstroom: CJBF.

Engelbrecht, B J 1982. Tydelik-deeltydse predikantsbediening in Reformatoriese lig (1967). Versamelde opstelle, Deel IV. Pretoria: Universiteit van Pretoria

Goumaz, L 1964. Het ambt bij Calvijn. Franeker: Wever.

Milner, B C 1970. Calvin's doctrine of the church. Leiden: Brill.

Nederduitse Gereformeerde Kerk. Algemene Sinode 2002. Kerkorde 2002. Wellington: Lux Verbi.

Nederduitsch Hervormde Kerk van Afrika. Algemene Kerkvergadering 1967. Notule van die Algemene Kerkvergadering 1967. Argief van die Nederduitsch Hervormde Kerk, Pretoria.

Nederduitsch Hervormde Kerk van Afrika. Algemene Kerkvergadering 1970. Notule van die Algemene Kerkvergadering 1970. Argief van die Nederduitsch Hervormde Kerk, Pretoria.

Nederduitsch Hervormde Kerk van Afrika. Algemene Kerkvergadering 1989. Agenda van die Algemene Kerkvergadering 1989. Argief van die Nederduitsch Hervormde Kerk, Pretoria.

Nederduitsch Hervormde Kerk van Afrika. Algemene Kerkvergadering 1992. Kerkwet van die Algemene Kerkvergadering 1992. Argief van die Nederduitsch Hervormde Kerk, Pretoria.

Nederduitsch Hervormde Kerk van Afrika. Algemene Kerkvergadering 2001. Agenda van die Algemene Kerkvergadering 2001a. Argief van die Nederduitsch Hervormde Kerk, Pretoria.

Nederduitsch Hervormde Kerk van Afrika. Algemene Kerkvergadering 2001. Notule van die Algemene Kerkvergadering 2001b. Argief van die Nederduitsch Hervormde Kerk, Pretoria. 
Nederduitsch Hervormde Kerk van Afrika. Algemene Kerkvergadering 2001. Kerkorde van die Algemene Kerkvergadering 2001c. Argief van die Nederduitsch Hervormde Kerk, Pretoria.

Nederduitsch Hervormde Kerk van Afrika. Algemene Kerkvergadering 2004. Notule van die Algemene Kerkvergadering 2004. Argief van die Nederduitsch Hervormde Kerk, Pretoria.

Pelser, G M M 1995. Die kerk in die Nuwe Testament. HTS 51, 645-676.

Plomp, J 1969. De kerkelijke tucht bij Calvijn. Kampen: Kok.

Pont, A D 1969. Aantekeninge oor die toelating tot die amp van dienaar van die Woord van proponente en teologiese studente wat aan die Universiteit van Pretoria voltyds besig is met die dosering van vakke wat as voorbereidend vir die teologiese studie beskou kan word. Ongepubliseerde memorandum, Pretoria.

Pont, A D 1973. Tydelik - deeltydse predikante. HTS 28, 97-117.

Pont, A D 1976. Amp en roeping. HTS 32, 168-180.

Pont, A D 1978. Waar begin en waar eindig die amp. HTS 34, 49-59.

Pont, A D 1981. Die historiese agtergronde van ons kerklike reg, Deel 1. Pretoria: HAUM.

Steubing, H 1985. Bekenntnisse der Kirche. Wuppertal: Brockhaus verlag.

Van Aarde, A G \& Pelser, G M M 2001. 'n Oop en vry teologiese debat met werklike diepgang. HTS 57, 7-48

Van Wyk, B J 1991. Die presbiteriaal-sinodale kerkbegrip. Pretoria: Kital. 